\title{
THE FIRST MAJOR GRAMMARS OF ENGLISH AND ROMANIAN: A COMPARATIVE APPROACH
}

\author{
DANIELA DOBOŞ \\ Alexandru Ioan Cuza University of Iaşi
}

\begin{abstract}
If the history of the English language is the story of its written texts, the same holds true for the history of the Romanian language, and in both cases the first grammars played a major part in the shaping up of the respective vernaculars. The paper proposes a comparative approach to the beginnings of codified grammars in English and Romanian, with a focus on those that are deemed to be the first major works- Robert Lowth's A Short Introduction to English Grammar (1762) and Samuil Micu and Gheorghe Şincai's Elementa linguae daco-romanae sive valachicae (1780). This approach considers topics such as why grammars might have been desirable in the eighteenth century (the political factor), and the functions of 'grammars', which are relevant in both cases; what language was actually codified, as well as the role of Latin in this enterprise, since it is worth noting that while English and Romanian belong in different language families, Latin was a formative element in both, ever since the territories of the two respective countries marked the North-Western and South-Eastern borders of the Roman Empire.
\end{abstract}

Keywords: codified grammars; the English; Latin; Romanian and Slavonic languages.

In truth, the easier any subject is in its own nature, the harder it is to make it more easy by explanation.

(Robert Lowth, Preface to A Short Introduction)

\section{Introduction}

Notwithstanding the geographical and cultural distance between Britain and Romania, one off Europe's West coast, the other on its South-Eastern margins, but brought together for two centuries as borders of the Roman Empire, the long-standing cultural relations between them are generally acknowledged in many books and essays which now go both ways, e.g. Deletant 2013; DraceFrancis 2013; Gavriliu 1998. 
From the linguistic perspective, the most significant aspect of these relations must be language teaching and learning, which historically goes mainly one way, with English nevertheless a latecomer in the field of foreign language studies, given that for a long time the official languages in the Romanian provinces were Greek and Slavonic. It is worth noting that long before English was introduced into Romanian school curricula, young men ("stayed men") from Transylvania had traveled to England to learn the language as early as the $17^{\text {th }}$ century, if we are to believe John Milton's Areopagitica of 1644 (1957/2003:743), a situation which can be accounted for in terms of the affinities between Protestant Transylvania and Puritan England, since some of those young men went there to study theology. There is evidence that in the second half of the $19^{\text {th }}$ century English was taught in colleges in Aiud and Alba Iulia.

In Iaşi in the $19^{\text {th }}$ century, within the Junimea literary society, there was interest in the English education system. Thus in 1893, only five years after the future King Edward VII had visited Bucharest, Tereza Strătilescu, a University of Iaşi history and philosophy graduate and a feminist, obtained a scholarship to Oxford University on the advice of A.D. Xenopol in order to study the English education system, and presumably also to learn English. Petre P. Carp was a member of Junimea who admired English culture and could speak the English language, so that he must have made his Shakespeare translations from the original (Săteanu 79), while historian A.D. Xenopol learnt English while studying in Berlin.

In 1919 (a century ago) the Ministry of Instruction decreed the introduction of English as an elective subject in higher education, while also providing for its introduction on the curricula of those secondary schools which were able to secure teaching staff. The first university English chairs were those of Cluj (1872) and Czernowitz (1904) under the Austria-Hungary administration, while the chair at the University of Iaşi was the first in the free Romanian state, following the First World War (decision taken in August 1919; chair occupied in 1926). In 1922 a Romanian chair was established in London, served by Marcu Beza, and an Anglo-Romanian Association was set up in London in 1927 with Queen Marie's support. This association organised conferences besides promoting the study of English, while also publishing The Roumanian Quarterly with contributions from Romania's top intellectuals (Chiţoran, "Înființarea Catedrei" 5). All these developments can be subsumed to Romania's French and British-oriented foreign policy following the First World War, where Queen Marie's contribution cannot be overstated.

The development of the first language studies was the second aspect in the linguistic relations between the two countries. These appear to have begun with Gramatica vie a limbei engleze of 1947, authored by Dragoş Protopopescu, a University of London graduate later a professor in Bucharest, who fell victim 
to communist terror when English was decreed "an imperialistic language", followed by Leon Leviţchi's Gramatica limbii engleze of 1961 (second edition with Ioan Preda in 1967). Beginning in the 1960s, during the short-lived liberalization period when Romania was feverishly assimilating Western culture, many linguistic studies on English were published, mainly as university courses, besides the remarkable Romanian-English Contrastive Analysis Project which began in 1970 and produced a large number of grammatical studies on a wide range of topics in the syntax and morphology of both languages, "with an emphasis on the pedagogical values of the studies" (Chiţoran "Report" 11).

\section{The Historical Contexts}

A comparison of the first major grammars of English and Romanian, Robert Lowth's A Short Introduction to English Grammar with Critical Notes (1762) and Samuil Micu and Gheorghe Şincai's Elementa linguae daco-romanae sive valachicae/ The Elements of the Dacian-Roman or Romanian Language (1780) can be held to continue that contrastive project. From the start, although compiled thousands of kilometers apart, a few similarities are easily noticeable, beginning with the common cultural context - both grammars fit the Enlightenment ideals of order, reason and regularity, while grammar was perceived as a way of 'ordering' language. Both were codified by individuals rather than academies or scientific societies before linguistics established itself as a discipline on its own. Their respective authors were clergymen and polymaths - Robert Lowth, D.D., later Lord Bishop of Oxford, a noted biblical critic and scholar of Hebrew who, according to David Crystal, published his grammar anonymously (2005: 396); Samuil Micu/ Samuele Klein de Szad, a confessor and director of studies in the Greek-Catholic College of Santa Barbara in Vienna, held to be the first Romanian language scholar (Puşcariu 217) and Gheorghe Şincai/ Georgio Gabriele Sinkai, Th.D., of the same religious order, with a manifest interest in Romanian history.

Despite the fact that nationalist feelings inspired both books, cultural insecurity was a feature of both political contexts in which the two grammars were written, so that upon examining the respective contexts, the major differences between them begin to emerge, largely as a result of historical incongruities.

In this respect, it must first be noted that Britain had a tradition of linguistic scholarship going back at least to the Royal Society, to which the many English grammars that were compiled in the 18th century testify, as if in answer to Jonathan Swift's open letter to the Lord High Treasurer, A Proposal for Correcting, Improving and Ascertaining the English Tongue of 1712; these grammars allegedly "catered for the rising middle classes who had to be supplied with new norms of speaking and writing correctly" (Fitzmaurice 321). 
In the Romanian provinces there was very little to no linguistic scholarship prior to the second half of the $18^{\text {th }}$ century, when interest in language regulation arose side by side with the idea of discovering the origins of the Romanian language (Iordan, Istoria lingvisticii 15).

In the $18^{\text {th }}$ century English had reached Late Modernity and its latest stage in the standardization process, while Pre-Modern Romanian emerged only in the first half of the $19^{\text {th }}$ century, when writers were deploring "the insufficiency" of the language, which prevented them from expressing their thoughts and ideas (Istrate 190). Furthermore, the remarkable language scholar Lazăr Şăineanu noted that "prior to the first quarter of the $19^{\text {th }}$ century, Romanian was practically ignored in Western Europe", if not "looked down upon as a Slavic or Slavic-Roman dialect” (1895: 37) mainly as a result of its Old Church Slavonic script.

Two more features that the two grammars share is their influential status and their roots in the Latin tradition: both were subsequently used as models for a host of other similar works. Micu and Şincai's is the first printed grammar of Romanian and the first to have used the Roman alphabet (Avram 575; Iordan, Istoria limbii 70), as well as the first work of the Şcoala Ardeleană (The Transylvanian School Cultural Movement), whose members sought to obtain social and political rights for the Romanians, equal to those of the Hungarians, Saxons and Szeklers, based on the Latin origin of the Romanian language and the uninterrupted Romanian presence in Transylvania (Rosetti 77). The title of the grammar is indicative of the fact that it is written in Latin. The poet and playwright Lucian Blaga noted that "the scholars of Şcoala Ardeleană, and especially the three luminaries: Samoil Clain, Gheorghe Şincai and Petru Maior, were justly obsessed with the idea that they had only their lifetimes to raise to the spirit of the Enlightened Age a people who was centuries behind. [...] They viewed books and learning as the means to a historic leap forward, which had to be achieved at all costs” (128-9). Micu and Şincai's Elementa was authored mainly for the use of foreigners, as Şincai himself suggests in his preface. Thus the major aim of this nationalist grammar was in fact political.

Robert Lowth's grammar, the most authoritative in 18th century Britain (over 30 reprints during the author's life time and subsequently copiously plagiarized), was in fact compiled for Lowth's eldest son, Thomas Henry, as a means of facilitating his learning of Latin by the time he would enter grammar school (Tieken-Boon van Ostade, "Grammars" 11-12). Thus this grammar is also firmly rooted in the Latin tradition; its title, for example, appears to have been inspired by a Latin grammar used by 18th century schoolboys, Lily's Short Introduction to Grammar. Lowth could not have ignored Latin grammar, as English grammar writing was "firmly entrenched in the Latin tradition until well into the eighteenth century" (Tieken-Boon van Ostade, "Grammars" 7). The Latin quotation from Cicero on the title page attests to this. 
On the other hand, Lowth's correspondence with his publisher shows that he was well-informed with respect to recent publications in the field, and researchers argue that he "looked like a language expert par excellence" (Chapman 27), having been educated at one of the finest grammar schools before going on to the New College at Oxford, where later he held a chair in poetry. As mentioned above, Lowth's grammar has been argued to have been aimed at allowing "the middling orders of society" access to "polite language" (Watts 48). The fact that Lowth indeed criticizes "the politest part of the nation" in his preface supports this idea. 'Polite language' would be "a use of English which was widely intelligible and acceptable - polished, elegant, correct. It was the correctness which was the ultimate guarantor of its politeness" (Crystal, The Stories 371).

\title{
A Brief Comparison of the Two Prefaces
}

Lowth’s 8-page preface begins with a powerful one-sentence argument:

\begin{abstract}
"The English language hath been much cultivated during the last two hundred years. It has been considerably polished and refined; its bounds have been greatly enlarged; its energy, variety, richness and elegance have been abundantly proved, by numberless trials, in verse and in prose, upon all subjects, and in every kind of style: but, whatever other improvements it may have received, it hath made no advance in grammatical accuracy” (1799: iii).
\end{abstract}

Next, in order to justify the grammar's subtitle "With Critical Notes", Lowth cites Jonathan Swift's then 50-year-old "public remonstrance" addressed to the Earl of Oxford concerning "the imperfect state of our language", which "in many instances offended against every part of grammar" (1799: iii). Indeed, Swift had described his century as "this Age of Learning and Politeness" (Crystal, The Stories 371). Lowth made it clear that it was the English as "spoken by the politest part of the nation" and "as it stands in the writings of the most approved authors" that often offended against grammar (1799: iv) before returning to the linguistic presentation in surprisingly modern terms: "the English language is perhaps of all the present European languages by much the most simple in its form and construction. [...] The construction of this language is so easy and obvious that our grammarians have thought it hardly worth while to give us anything like a regular and systematical syntax". Finally, "it is not the language, but the practice that is in fault" (1799: v-vi).

The entire preface provides evidence of its author's linguistic expertise, but in his discussion of the designs of grammar he again appears modern in his outlook: 
"The principal design of a grammar of any language is to teach us to express ourselves with propriety in that language; and to enable us to judge of every phrase and form of construction, whether it be right or not. The plain way of doing this is, to lay down rules, and to illustrate them by examples. But beside shewing what is right, the matter may be further explained by pointing out what is wrong. [...]. Besides this principal design of Grammar in our language, there is a secondary use, to which it may be applied [...]: the facilitating of the acquisition of other languages, whether ancient or modern. A good foundation in the general principles of grammar is in the first place necessary for all those who are initiated in a learned education. Universal Grammar cannot be taught abstractedly, it must be done with reference to some language already known; in which the terms are to be explained and the rules exemplified” (1799: viii).

Although Lowth's conception of Universal Grammar may have consisted largely of the application of Latin grammar to other languages, his focus on practice rather than the language system emerges quite clearly from the preface; in fact the author puts it quite plainly: "in a word, it was calculated for the use of the learner, even of the lowest class". "Those who would enter more deeply into this subject" were recommended James Harris's Hermes (1751), "the most beautiful and perfect example of analysis that has been exhibited since the days of Aristotle” (1799: x), which was a rather forbidding philosophical grammar.

The 8-page preface to Elementa linguae daco-romanae sive valachicae was authored by Georgio Gabriele Sinkai in Latin, so that present-day Romanian readers without any knowledge of the language must have recourse to its translation in the bilingual edition prepared by Mircea Zdrenghea, which was published at its bicentennial, in 1980. In the 18th century, Latin was the international language and foreign linguists would have been able to read it; Friedrich Diez's Grammar of Romance Languages of 1836 included Romanian in the family of Romance languages (Iordan, Istoria limbii 70). The political objective underlying the grammar is made clear from the first paragraph of the preface, which deploys the historical argument: "Seventeen centuries have passed since Trajan, after he had defeated Decebalus, colonized unpopulated Dacia. Those who know anything about history will understand easily the numerous important changes that the descendants of the Romans have been exposed to since then" (1980: 3). The second paragraph introduces "the Latin language of our ancestors", which had changed to a great extent, not least because of the introduction of "the written Slavic Language"” in Church services under Bulgarian influence, which among other things had resulted in "language degradation" (orig. barbarismum) (1980: 4-7). Şincai then explains that although the grammar had been written at the request of "the Dacian-Roman students in the St. Barbara Greek College”, it was intended for wider use by tradesmen and 
travellers to the principalities who would need the Dacian-Roman language (1980: 9).

Thus for Şincai, as for the other members of the Transylvanian School the Latin origin of the Dacian-Roman language coincided with its speakers' ethnic origins as descendants of the Romans; in order to argue this idea Micu and Şincai compiled their grammar in Latin and presented Romanian and classical Latin as very similar employing what has been termed etymological spellings, i.e. the adaptation of Romanian spellings to their Latin etymons (Latinization), in accordance with the principles set forth in Micu's Carte de rogaciuni of 1779 . Underlying the etymological spelling system was the two authors' deep-seated wish to turn Romanian to the use of the Roman alphabet. At the beginning of the Introduction to his History of Romanian Philology of 1895, Lazăr Şăineanu remarks on the century that had passed since 1780 and 1787 when the first grammars had been published:

\begin{abstract}
"while Văcărescu [...] limits himself to the objective recording of linguistic data, according to use, which he deemed the only principle in matters of language, Klain and his followers introduced the subjective principle in Romanian philology [...] adopting $18^{\text {th }}$ century ideas concerning the artificial character of speech" (1895: 2). [Ianache Văcărescu's Observaţii sau băgări-dă-seamă asupra regulelor şi orânduelelor gramaticii rumâneşti was the first grammar to be printed in Romanian with Latin terminology]
\end{abstract}

\title{
A Comparison of the Contents and Structures of the Two Grammars
}

Robert Lowth's A Short Introduction consists of two main parts - the text and the running footnotes, which are particularly elaborate in the syntax section. The text contains reasonably simple statements about English, while the more complex issues are addressed in the footnotes, which also include analyses of grammatical mistakes by well-known authors, aimed to point out the need for his readers to study grammar systematically: "the necessity of investigating the principles of it [the English language] and studying it grammatically, if we would attain to a due degree of skill in it" (1799: vii). It is also in the footnotes that the strong proscriptions were expressed. Lowth had collected sufficient grammatical mistakes from works by the best-known authors, which he believed to some extent representative of general usage, to be able to base his grammar on them and he was the first to take this approach (Tieken-Boon van Ostade, The Bishop's Grammar 2). Thus A Short Introduction emerges as a normative grammar, "which fit into the $18^{\text {th }}$ century tradition of grammarians, rhetoricians and lexicographers adhering to the principles of purity, perspicuity and precision of expression” (Yáñez-Bouza 255-6), but one which was also descriptive. 
The text begins with a definition of grammar, which reflected the philosophical concern for linguistic universals as expressed in the Port-Royal Grammar:

\begin{abstract}
"Grammar is the art of rightly expressing our thoughts by words. Grammar in general, or universal grammar, explains the principles which are common to all languages. The grammar of any particular language, as the English Grammar, applies those common principles to that particular language according to the established usage or custom of it” (1799: 1).
\end{abstract}

The concise presentation of the concept of grammar continues with morphology-definitions of letters, vowels and consonants and their pronunciations with examples. It is worth noting that throughout the book, all the grammatical concepts introduced are first defined. Next, syllables and spelling are defined, before the "Introduction to Words", which are "articulate sounds, used by common consent, as signs of ideas or notions" (1799: 5-6). This definition coincides with John Locke's concept of words, which "stand for nothing, but the Ideas in the Mind of him that uses them" (1690/1975: 405). Lowth then briefly describes "nine sorts of words" or "Parts of Speech" by their main uses: the Article; the Substantive or Noun; the Pronoun; the Adjective; the Verb; the Adverb; the Preposition; the Conjunction and the Interjection e.g. "The Adverb; added to verbs, and also to adjectives and other adverbs, to express some circumstance belonging to them", before taking them up again in turn to be illustrated by a profusion of examples, mainly from the Bible, as in the discussion of Definite and Indefinite Articles (1799: 10-14).

In the presentation of Substantives or Nouns, defined as names of things, "of whatever we conceive in any way to subsist, or of which we have any notion" (1799: 14), Lowth focuses on the two English cases - the nominative and the possessive, and on the absence of gender. In his presentation of Adjectives, he argues that "double comparatives and superlatives are improper”, such as Shakespeare's "more braver" (1799: 27) and Dryden's “worser” (1700: 29), and criticizes the use of adjectives instead of adverbs, "improperly, and not agreeably to the genius of the English language, as 'indifferent honest; excellent well' (Shakespeare)" (1799: 92). "You was" he deems "an enormous solecism" (1799: 34).

The presentation of verbs, "words which signify to be, to do or to suffer" (1799: 29) includes accurate descriptions of active and passive forms, transitive and intransitive uses, the markings for person, number, time and mode, which is defined and explained in note 3. (1799: 32). Lowth also accurately records "the peculiar force of the several auxiliaries" (1799: 40) in the formation of interrogatives and negatives and "to supply the place of another verb", besides 
what modern grammarians call the modal meanings of auxiliaries. He also emphasizes the distinction between would and should: the former "primarily denotes inclination of will", the latter "obligation" (1799: 41) as well as that between shall and will: "Will in the first Person singular and plural promises or threatens; in the second and third Persons only foretells: shall on the contrary, in the first Person simply foretells; in the second and third Persons commands or threatens" (1799: 41).

A lengthy presentation is devoted to Irregular Verbs, beginning with the observation that "the formation of verbs in English, both regular and irregular, is derived from the Saxon" (1799: 47) and including the relationship between stress and pronunciation. Most of the forms of irregular verbs indicated are used in present-day English. Lowth also criticizes "the very great corruption by which the form of the past time is confounded with that of the participle" as in Milton's "He would have spoke"; "he begun for he began, he run for he ran, he drunk for he drank" (1799: 60-1). Lowth also posited that "two negatives in English destroy one another, or are equivalent to an affirmative" (1799: 94), though he was not the first grammarian to do so (Tieken-Boon van Ostade, The Bishop's Grammar 11).

The second part comprises syntax, without being named as such; the title is "Sentences" and this section takes up approximately one third of the book. Following the definition of Sentences, the notion of Phrase is introduced, as "two or more words rightly put together, in order to make a part of a sentence; and sometimes making a whole sentence" (1799: 68) and 12 types of phrase are further identified. The syntax section is accompanied by ample footnotes where more complex points are detailed side by side with examples from the Gospels and the best-known authors. A short section deals with Punctuation before the final "Praxis, or Example of Grammatical Resolution" (analysis).

Lowth's Short Introduction was an important step along the codification process of the English language, which was part of the larger standardization process. David Crystal points out that

\begin{abstract}
"The aims of the early grammarians were threefold. They wanted to codify the principles of their languages, to show that there was a system beneath the apparent chaos of usage. They wanted a means of settling disputes over usage. And they wanted to point out what they felt to be common errors, in order to 'improve' the language. [...] Where usage was divided, one version would be prescribed [...]; others would be proscribed"
\end{abstract}

before noting that "only a few dozen rules were ever the focus of grammatical prescriptivism - around 1\% of the 3.500 or so features of English grammar" (How Language Works 453). Recent research has shown that the negative perception of Lowth's grammar by many present-day linguists is 
unfounded; for example, its alleged almost exclusive concentration on written language (Pullum 66). In his discussion of what is today known as preposition stranding, Lowth argues that

"the Preposition is often separated from the Relative which it governs, and joined to the Verb at the end of the Sentence, or of some member of it: as, 'Horace is an author, whom I am much delighted with.' [...] This is an Idiom which our language is strongly inclined to; it prevails in common conversation, and suits very well with the familiar style in writing; but the placing of the Preposition before the Relative is more graceful, as well as more perspicuous; and agrees much better with the solemn and elevated Style” (1799: 95-96).

This paragraph shows that Lowth distinguished between language styles - "common conversation" and "the familiar style in writing" and also that his strictures were not in fact formulated prescriptively (which is another alleged fault), but descriptively. The very fact that he quoted a profusion of examples of poor English to support his arguments means that he showed language in use. Henry Hitchings suggests, somewhat dismissively, that "the Short Introduction represents the general condition of English grammars up until the twentieth century: there is a reluctance to wrestle with difficult questions, an emphasis on using literature to illustrate aspects of language, an affection for examples and learnable points rather than larger rational procedures, an inherited set of labels that are variably used, and a rarely explored awareness that there is something wrong with all of this” (42).

In fact, Robert Lowth's Grammar stands next to another monument of English, Samuel Johnson's Dictionary of 1755 . Not only were Johnson and Lowth contemporaries, but both were Robert Dodsley's publishing projects, and the Short Introduction was marketed in a remarkably modern manner. Henry Hitchings further writes, in his trademark witty style, that "it is tempting to imagine an encounter between them, given that Dodsley, a powerful publisher, was their mutual friend, but there is no evidence that they met”. [...] The Short Introduction was popular not only in Britain but also in America and Germany, and was still being actively used by students in leading American universities such as Harvard almost a hundred years after its publication” (41). David Crystal in turn rightly argues that "reading through these early grammars, we cannot but be impressed by the detailed grammatical knowledge they display. A great deal of the analysis is accurate and perceptive, and might appear - with minor terminological adjustments - in any modern descriptive grammar" (The Stories 397).

Micu and Şincai's Elementa linguae daco-romanae sive valachicae contains four main parts. The first part, De Ortographia / On Orthography, begins with chapter I of three, which states that "the old Dacian-Roman letters 
are the Latin ones” (1980: 11) before setting up pronunciation rules for the Latinized spellings; in the process many of the phonological rules that account for the change of Latin sounds into Romanian are correctly identified (Ionaşcu 17; Puşcariu 20). Present-day linguists argue that Micu and Şincai were aware of the fact that language changes are subject to rules, as the following observation shows: "This second rule is given so that we may easily derive words from their Latin originals [with reference to Latin intervocalic $l$ changing into $r$ ] and to show that this is a general rule of change" (1980: 15) and elsewhere: "we want to explain in detail and formulate as accurately as possible the rules for deriving Romanian words from Latin ones” (1980: 81). Although the formulation of these rules inevitably included some inaccuracies, including the occasional confusion of sounds and letters, the two authors were the very first scholars of Romanian historical phonetics and morphology.

Part II, De Etymologia/On Etymology, which in fact deals with morphology, contains 17 chapters on articles (I); names (nouns), pronouns and adjectives (II-IX); numbers/ numerals (X); auxiliary verbs and the conjugation of regular and irregular verbs (XI-XIII); adverbs (XIV); prepositions (XV); conjunctions (XVI) and interjections (XVII). That the two authors modelled their presentation of Romanian morphology on Latin grammar is obvious given the fact that the cases of nouns include the Ablative, e.g. de la vecinul, while the conditional is deemed a form of the conjunctive. In fact all the grammar terms employed are Latin e.g. praeteritum, imperfectum, plusquamperfectum, meant to model the Romanian verb paradigm on the Latin one. Forms which do not exist in Romanian are also introduced, e.g. fiitor, a future participle. There are nevertheless many accurate classifications and morphological descriptions, including the rules for establishing the gender (masculine or feminine) of nouns according to their inflections (chapter IV), the descriptions of personal, possessive, reflexive, demonstrative, interrogative, relative and indefinite pronouns, as well as the conjugations of verbs, which is no mean achievement, given the complexity and difficulties of Romanian grammar.

Part III, De Syntaxi/On Syntax, contains four chapters and an appendix, titled On the Derivation of Dacian-Roman Words from Latin, which enlarges on the phonetical and morphological rules for the derivation of Romanian nouns. Much like Latin grammars, this part contains orderly syntactic rules and descriptions of the parts of speech in context with a focus on those constructions which differ from Latin, including comparisons with other languages - Italian, German and Hungarian (1980: 71-73). That the syntax part is very short can be accounted for by the fact that in the days before linguistics became established as a discipline, syntactic units or constituents and other intricate workings were unknown. The longest chapter is chapter III, which deals with the syntax of verbs which, the authors suggest, "is practically identical with that of Latin verbs”, e.g. Am fost in Roma; Siede in Bucuresci; 
Quand ai trecut pen Iási?; Me voi duce la vara (1980: 78). Chapter IV is the shortest, since "the syntax of these parts of speech (adverbs, prepositions, conjunctions and interjections) is very similar to the Latin one, so that no special rules need be given”, e.g. Au venit delá Imperátul Turcesc lá Imperátul nostr á Romanilor un Trimis (1980: 80).

Part IV contains the Vocávullar Romanesc si Latenesc/ Romanian and Latin Vocabulary, including five Forme de Vorbit despre lucrurile celle ce mai adese-ori ven in cuventare. The vocabulary groups words into semantic categories: I. Despre Dieu, Spiriti (Duchuri) si celle ce se cuven lor; II. Despre Lume si despre Elementuri; III. Despre Pamant; IV. Despre Temp; V. Despre hom si despre partile homului; VI. Despre scaderile homului; VII. De Vestmente; VIII. De celle de lipse in cása; IX. De celle ce se áfla in Grájd; X. De Legumi ; XI. De Arbori si de Pome ; XII. Despre Páseri, Vite, Fere ; XIII. De Vietiuitorii ne taliáti; XIV. De Metálluri; XV. De Colori and XVI. De Fratie si Cognatie. This vocabulary contains 486 words, of which 336 are of Latin origin (Zdrenghea 1980: xx).

The Forme de Vorbit are conversation items as used in introductions, at table, time and the weather and more, which are the equivalent of the modern conversation guide, e.g. Bona demineatia, Domnule! Qvum traesci? Esti sanatòs?; Ásterneti mása, qua indáta vor báte doa spra diece; Quáte hore sent? Merge pe noue; Nu cunosci pe cutáre? The fifth dialogue, Un nemernic intreaba delá un cetatián unde sede cutáre, begins with Scii domniea ta Romanesce? / Do you speak Romanian? (1980: 108), which represents the first and only use of the noun Romanesce/ Romanian rather than Dacian-Roman. It is interesting to note that from the first chapter, the authors often address their readers directly, e.g. "Take care, dear reader, to always place the particles a, pe and de la before a genitive, accusative and ablative, but place the article at the end of the declined name (1980: 25); "Now, enlightened reader, you have enough examples of all the declensions. You should only take note of the fact that..." (1980: 29).

In 1805, in his preface to the second edition, Şincai pointed out very clearly the goals of the Elementa: "we strove to demonstrate in every possible way the descent of the Romanian language from Latin and also to teach Romanian to readers with a sound knowledge of Latin by means of a much easier method" (1980: 117). However, as the examples above show, quite a few etymological spellings were exaggerated, so it is little wonder that this attracted criticism (Blaga 181). Lazăr Şăineanu pointed out that the Elementa stands out as the first work that employed the Roman alphabet, but its etymological spellings may have been responsible for its limited influence, since beyond the Carpathians the Roman alphabet only took root in the $19^{\text {th }}$ century (93). 
Another apparent flaw of this work is the two authors' mistakenly considering Romanian to be descended form classical Latin rather than the sermo rusticus, a fact harshly criticized by Şăineanu (124-126):

\begin{abstract}
"The single word soare (sun) reflects the two changes which separate it from its original and give it its national character. The two phonetic changes -the rhotacism of $l$ and the diphongization of $o$, characterize our language but are unknown to its sister languages. They occurred during the early stages in the development of Romanian [...]. To say sole instead of soare is to turn the language back several centuries" (Şăineanu 128).
\end{abstract}

Şăineanu put such efforts of Romanizing or perfecting the Romanian language in the wider context:

"The whole $18^{\text {th }}$ century was dominated by the belief in the perfectibility of speech. The ideologists of the time, who considered language a man-made mechanism, entertained the possibility of perfecting its structure [...] just like any other human invention, say a machine or a clock [...]. It lay in the grammarian's power to correct or reform spoken language, and proceeding from a purported perfect form, declare a language proper or barbaric, disregarding completely its historical evolution” (119-120).

\title{
Conclusions
}

As I have already shown, the two grammars, compiled on the Western and Eastern margins of the continent, fit the Enlightenment ideals of order, reason and regularity, at a time when grammar was perceived as a way of 'ordering' language. Both grammars were products of the codification and standardization of the respective languages, and were consequently normative to a large extent. In both cases linguistic and social correlations can be identified. The Elementa aimed at enriching and perfecting the language and paved the way for the shaping of "modern literary Romanian" as a language of culture in the wider context of the Transylvanian School; the Short Introduction too aimed at "improving" the language, while also catering to the upwardly mobile middle classes, which were keen to learn "polite' language.

The intellectual concern with the improvement of English can further be noted in the rhetorical grammars and works on elocution published in the same period by Thomas Sheridan and John Walker, among others. The English of the Short Introduction is remarkably like present-day English, while the Romanian of the Elementa is to a large extent $18^{\text {th }}$ century Romanian. Romanian works on elocution appeared in the $19^{\text {th }}$ century, e.g. Ion Molnar-Piuariu, Retoricăa, adecă invătătura şi intocmirea frumoasei cuvântări (1798) and S. Marcovici, Curs de 
retorică, Bucureşti, Tipografia Eliad (1834). It is worth noting that while in England the upper and middle classes contributed to the improvement of the national language, in the Romanian Provinces the upper classes spoke Greek and then French, so that they did not have any influence on the shaping up of the language. Romanian literary language was based on the old language used in the Church (Ibrăileanu and Densusianu, quoted in Istrate 197 and 203).

Both grammars were codified by individuals rather than academies or scientific societies; their respective authors were clergymen and polymaths, as detailed at the beginning of the paper. While the Short Introduction "was calculated for the use of the learner, even of the lowest class" (Lowth 1799: x), the Elementa too was calculated for prospective foreign learners who might have needed the language. The structures of the two works were similar to a great extent, dealing with morphology before syntax and the linguistic units; the Short Introduction, however, is also definition-oriented.

Both grammars were rooted in the Latin tradition, though in different ways. In $18^{\text {th }}$ century Britain the linguistic goals had changed from the assimilation of English into Latin grammatical categories to its improvement and refining, and the Short Introduction typifies this process, as Robert Lowth may have used Latin grammatical categories to some extent but his goal was the description of (accurate) English structures. The Elementa went in the opposite direction as it were, because Micu and Şincai's etymological spellings are tantamount to a return to Latin since the grammar's main goal was to testify to the Latin origins of the Romanian language and turn it to the use of the Roman alphabet. Thus while the Short Introduction aimed at breaking away from Latin, the Elementa embraced it wholeheartedly, using Latin to describe the grammar of Romanian, called "Dacian-Roman", in an effort to break away from the Slavonic language. While Robert Lowth focused on "practice" rather than the language system (1799: v), and further distinguished between speech and writing and levels of style, no such distinctions characterize the Elementa, since it aimed at elevating the language as a whole.

Last but not least, both grammars were extremely influential. The Short Introduction was "frequently reprinted during Lowth's own lifetime and well beyond, and was pirated, pilfered, and plagiarized. It was, moreover, the first English grammar that was marketed "in a way that reminds us of modern publishing practices, and this resulted in what was then an unprecedented numbers of copies printed" (Tieken-Boon van Ostade, The Bishop's Grammar 1). Henry Hitchings notes that "students were certainly made to learn Lowth's Grammar. They were expected to memorize the rules and then recite them. Ditto the examples" (43). The Elementa paved the way for a host of other $19^{\text {th }}$ century grammars which used fewer Slavic terms and more Latin ones. The Romanian $19^{\text {th }}$ century intellectuals' struggle for language proves the importance of Micu and Şincai's work. 


\section{References}

Avram, Mioara. “200 de ani de la prima gramatică tipărită a limbii române”. Limba română, XXIX/ 6 (1980): 573-585. Print.

Blaga, Lucian. Gîndirea românească în Transilvania în secolul al XVIII-lea. Bucureşti: Editura Ştiinţifică, 1966. Print.

Chapman, Don. “The eighteenth-century grammarians as language experts”. Grammars, Grammarians and Grammar-Writing in Eighteenth-Century England. Ed. Ingrid Tieken-Boon van Ostade. Berlin \& New York: Mouton de Gruyter, 2008: 21-36. Print.

Chiţoran, Dumitru. “Report on the Romanian-English Contrastive Analysis Project”. $2^{\text {nd }}$ International Conference of English Contrastive Projects. Ed. Dumitru Chiţoran. Bucharest: Bucharest University Press, 1976. 11-34. Print.

Chiţoran, Dumitru. ,Înfiinţarea Catedrei de limba şi literatura engleză a Universităţii din București sau cum să contracarezi, prin cultură, răspândirea influenţei germane în România”. Historia 2016 https://www.historia.ro/sectiune/general/articol/infiintarea-catedrei-de-limba-siliteratura-engleza-a-universitatii-din-bucuresti n.pag. Web. 13 May 2019.

Crystal, David. The Stories of English. London: Penguin, 2005. Print.

Crystal, David. How Language Works. London: Penguin, 2007. Print.

Deletant, Dennis. "Good wine needs a bush: The British Council and Romania, 1937 to 1990”. British Council. The Long and Winding Road. Recollections from our 75 years in Romania. Ed. Nigel Townson. British Council. 2013: 11-30. Print.

Drace-Francis, Alex. "Sex, Lies and Stereotypes: Images of Romania in British Literature, 1945-2000". The Traditions of Invention. Romanian Ethnic and Social Stereotypes in Historical Context. Leiden \& Boston: Brill, 2013: 233-249. Print.

Fitzmaurice, Susan. "The commerce of language in the pursuit of politeness in eighteenth-century England”. English Studies 79 (1998): 309-328. Print.

Gavriliu, Eugenia. Sindromul Gulliver. Brăila: Ed. Evrika, 1998. Print.

Hitchings, Henry. The Language Wars. A History of Proper English. London: John Murray, 2011. Print.

Ionaşcu, Romulus. Gramaticii români. Tractat istoric despre evoluţiunea studiului gramaticei limbei române de la 1757 până astăzi. Iaşi: Institutul de Arte grafice N.V. Ştefaniu \& Co., 1914. Print.

Iordan, Iorgu (coord.). Istoria lingvisticii româneşti. Bucureşti: Ed. Ştiinţifică şi Enciclopedică, 1978. Print.

Iordan, Iorgu. Istoria limbii române. Bucureşti: Ed. Ştiinţifică şi Enciclopedică, 1983. Print.

Istrate, Gavril. Originea limbii române literare. Iaşi: Ed. Junimea, 1981. Print.

Klein de Szad, Samuele \& Georgio Gabriele Sinkai. Elementa Linguae Daco-Romanae, sive Valachicae. Vindobonae: Typ. Josephi Nob. de Kurzböck, 1780. Print.

Locke, John. An Essay Concerning Human Understanding. Ed. Peter H. Nidditch. Oxford: Clarendon Press, 1975. Print.

Lowth, Robert. A Short Introduction to English Grammar with Critical Notes. Philadelphia: R. Aitken, 1799. Print. 
Micu, Samuil şi Gh. Şincai, Elementa linguae daco-romanae sive valachicae. Studiu introductiv, traducerea textelor şi note de Mircea Zdrenghea. Cluj-Napoca: Editura Dacia, 1980. Print.

Milton, John. Complete Poems and Major Prose. Edited, with notes and introduction by Merritt Y. Hughes. Indianapolis, In: Hackett Publishing Co, 2003. Print.

Nicolescu, Adrian. Şcoala Ardeleană şi limba română. Bucureşti: Editura Ştiinţifică, 1971. Print.

Pullum, Geoffrey K. “Lowth’s grammar: A re-evaluation”. Linguistics 137 (1974): 6378. Print.

Puşcariu, Sextil. “Despre legile fonologice”. Dacoromania II (1921-1922): 20. Print.

Puşcariu, Sextil. Limba română. Rostirea (vol.II). Bucureşti, 1959. Print.

Rosetti, Alexandru. Schiţă de istorie a limbii române de la origini şi pînă în zilele noastre. Bucureşti: Ed. Albatros, 1976. Print.

Săteanu, Cornel. Figuri din „Junimea”. Bucureşti: Editura „Bucovina”, 1932. Print.

Şăineanu, Lazăr. Istoria filologiei române. Studii critice. Bucureşti: Editura Librăriei Socec \& Comp., 1895. Print.

Tieken-Boon van Ostade, Ingrid. "Grammars, grammarians and grammar writing: An introduction”. Grammars, Grammarians and Grammar-Writing in EighteenthCentury England. Ed. Ingrid Tieken-Boon van Ostade. Berlin \& New York: Mouton de Gruyter, 2008. 1-14. Print.

Tieken-Boon van Ostade, Ingrid. The Bishop's Grammar: Robert Lowth and the Rise of Prescriptivism. Oxford: Oxford University Press, 2010. Print.

Văcărescu, Ianache. Observaţii sau băgări-dă-seamă asupra regulelor şi orânduelelor gramaticii rumâneşti. In Opere.Ed. Cornel Cîrstoiu. Bucureşti: Ed. Minerva, 1982. Print.

Watts, Richard J. "Grammar writers in eighteenth-century Britain: A community of practice or a discourse community?”. Grammars, Grammarians and GrammarWriting in Eighteenth-Century England. Ed. Ingrid Tieken-Boon van Ostade. Berlin \& New York: Mouton de Gruyter, 2008: 37-56. Print.

Yáñez-Bouza, Nuria. "Preposition stranding in the eighteenth century: Something to talk about”. Grammars, Grammarians and Grammar-Writing in Eighteenth-Century England. Ed. Ingrid Tieken-Boon van Ostade. Berlin \& New York: Mouton de Gruyter, 2008: 251-277. Print.

\section{BIONOTE}

Daniela Doboş is Associate Professor in the Department of English of the Faculty of Letters, “Alexandru Ioan Cuza” University of Iaşi, Romania. Her research interests are English and Romanian grammar and linguistics, specialized translation and cultural studies. She has published extensively in various journals and in various collections of essays. Among her latest articles are "Vulgar Slang in English and Romanian. A Few Notes on Romanian Hip Hop Lyrics Translated into English” in Argotica No 1(3)/2014 and "The West Going East: Archaic Romania in Western Authors' Travel Writings of the Late Twentieth Century" in Views of the East. Travel and Intercultural 
Daniela DOBOȘ

Communication in Europe, “Alexandru Ioan Cuza” Publishing House, 2016. She is the author of two books on English linguistics.

Email: dana_dobos@yahoo.com 
